\title{
Hepatocyte Nuclear Factor 3-Beta
}

National Cancer Institute

\section{Source}

National Cancer Institute. Hepatocyte Nuclear Factor 3-Beta. NCI Thesaurus. Code C73454.

Hepatocyte nuclear factor 3-beta (457 aa, $483 \mathrm{kDa}$ ) is encoded by the human FOXA2 gene. This protein plays a role in transcriptional modulation. 